\title{
Role of micronutrients in few crops production and human health in Lucknow region (U. P.), India
}

\author{
Pradip Kumar Maurya ${ }^{1 *}$, Hemant Kumar ${ }^{1}$, Manoj Singh Rawat ${ }^{2}$ \\ ${ }^{1}$ Department of Zoology and Environmental Science, Gurukula Kangari Vishwavidyalaya, Haridwar-249404 \\ (Uttarakhand),INDIA \\ ${ }^{2}$ Quality Control Lab, Biotech park, Sec-G, Jankipuram, Kursi Road, Lucknow-226021 (Uttar Pradesh), INDIA \\ *Corresponding author. E-mail: hemantjam@gmail.com
}

Received: April 9, 2015; Revised received: March 11, 2016; Accepted: June 7, 2016

\begin{abstract}
Accumulation of nutrients like $\mathrm{Ca}, \mathrm{Mn}, \mathrm{Cu}, \mathrm{N}, \mathrm{P}$, and $\mathrm{K}$ were determined in root, stem, and leaves of different crops. The selected crop is uses for different nutrients for the body growth, in all of the six crop plant were selected like Cajanus cajan (Arhar-A) Pisum sativum (Pea-B), Solanum tuberosum (Potato-C), Brassica juncea (Mustard-D), Cicer arietinum (Gram-E), and Triticum aestivum (Wheat-F). The present study indicated that the concentration of $\mathrm{Cu}$ highest in the potato leaf $(9.6 \mathrm{mg} / \mathrm{kg})$, Arhar stem $(9.6 \mathrm{mg} / \mathrm{kg})$ and Gram leaves $(8.8 \mathrm{mg} / \mathrm{kg})$. The concentration of cupper was found toxic to human health. The objective of this study was to investigate the concentration of nutrients specially cupper maximum in leaf of potato. These nutrients deficiencies in crop are not only hampering the crop productivity but also are deteriorating produce quality. High consumption of cereal based foods with low contents of nutrients is causing health hazards in humans. The contents of nutrients in food can be elevated either by supplementation, fortification or by agricultural strategies i.e., biofortification and nutrients containing fertilizers.
\end{abstract}

Keywords: Crop, Leaf, Nutrients, Root, Stem

\section{INTRODUCTION}

Macronutrients obtained from the soil include nitrogen $(\mathrm{N})$, phosphorus $(\mathrm{P})$, potassium $(\mathrm{K})$, calcium $(\mathrm{Ca})$, magnesium $(\mathrm{Mg})$, and sulphur $(\mathrm{S})$. The remaining essential elements are known as micronutrients, which are required in trace amounts; although these are in small quantity. They include boron (B), chlorine $(\mathrm{Cl})$, copper $(\mathrm{Cu})$, iron $(\mathrm{Fe})$, manganese $(\mathrm{Mn})$, molybdenum (Mo), and zinc $(\mathrm{Zn})$. Micronutrients are the essential elements that are used for the growth and regulation of the plant's vital physiological activities. (Bhargava et al., 2001) Agriculture micronutrient' market growth has increased progressively because of increased global micronutrient deficiency in soil and shrinkage in the world's agricultural land. The deficiency of micronutrients has increased worldwide due to intensive cropping pattern, extensive use of chemical fertilizers, mining of micronutrient reserves, and extensive irrigation facilities. Plant growth and development may be decelerated if any of these elements are lacking in the soil or are inadequately balanced with other nutrients. To replenish the crop's micronutrients requirement, micronutrients are applied to crops. The agriculture micronutrients market has gained worldwide importance in the recent past due to its effectiveness on quality and productivity of crops (DRI (2001).

Pulses in India have long been as a source of protein.
Pulses are grown on 22-23 million hectares of area with an annual production of 13-15 million tonnes (mt). India accounts for $33 \%$ of the world area and $22 \%$ of the world production of pulses. Pulse production is affected by a number of biotic and a biotic factors including others like inadequate marketing facilities and less recovery of pulses due to use of obsolete processing machines. Pulse are sources of supplementary protein to daily based, cereals and starchy food for a predominantly vegetation population and for those who cannot afford expensive animal protein. Pulses are there for often regarded as poor man meat they also provide energy, essential, vitamins and several compound conceded beneficial for good health. Their cultivation enriches soil by adding nitrogen and improves the physical, chemical and biological soil properties (Anonymous, 2002).

The pea is most commonly the small spherical seed or the seed-pod of the pod fruit Pisum sativum. Each pod contains several peas. Peapods are botanically a fruit, since they contain seeds developed from the ovary of a (pea) flower. The name is also used to describe other edible seeds from the Fabaceae such as the pigeon (Cajanus cajan), the cowpea (Vigna unguiculata), and the seeds from several species of Lathyrus. $P$. sativum is an annual plant, with a life cycle of one year. It is a cool season crop grown in many parts of the world; planting can take place from winter to early ISSN : 0974-9411 (Print), 2231-5209 (Online) All Rights Reserved @ Applied and Natural Science Foundation www.jans.ansfoundation.org 
summer depending on location. The average pea weighs between 0.1 and 0.36 grams. The potato was first cultivated in South America between three and seven thousand years ago, though scientists believe they may have grown wild in the region as long as 13,000 years ago. The genetic patterns of potato distribution indicate that the potato probably originated in the mountainous west-central region of the continent. The most probable place of origin of potatoes is located between the south of Peru and the north east of Bolivia (Brown, 2000).

Mustard is the third important oilseed crop in the world. It contributes about $28.6 \%$ in the total oilseeds production in India, where it is the second most important edible oilseed after groundnut sharing $27.8 \%$ in India's oilseed economy (Shekhawat et al., 2012). Rape/Mustard has been an important crop to India for a long period of time. At an average India produces around 5 million tons of rape/mustard annually. Indian mustard, Brassica juncea is predominantly cultivated in Rajasthan, UP, Haryana, Madhya Pradesh, and Gujarat (Shekhawat et al., 2012). Many insect pest species are found infesting mustard crop of which saw fly (Athalia lugens proxima), flea beetle (Phyllotreta cruciferae), leaf feeders like diamond back moth (Plutella xylostella), pod borer (Crocidolomia binotalis), cabbage butterfly (Pieris brassicae), aphids (Lipaphis erysimi, Brevicoryne brassicae and Myzus persicae) are important. Aphids are most common and destructive pests of brassicaceous crops across the World, and often cause heavy losses in yield (Shylesha et al., 2006). Among aphids, mustard aphid, L. erysimi (Hemiptera: Aphididae) is predominant and is a key pest of rapeseed and mustard causing $35-73 \%$ reduction in yield and 5-6\% reduction in oil content (Shylesha et al., 2006).

Among Vigna group, in economic terms, green gram is the most important pulse crop. It has strategic position in Southeast Asian countries for nutritional security and as a sustainable crop. Improved green gram cultivars have a narrow genetic base that limits yield potential and they are poorly adapted to varying growth conditions in different agro-ecological conditions. The genetic potential of landrace germplasm accessions in gene banks therefore needs to be better exploited (Bisht et al., 2004). India is the highest producer as well as consumer of pulses in the world and contributes $25.5 \%$ of total global pulse production (GOI, 2013). Greengram (Vigna radiata L.) is the third important pulse crop of India grown in nearly 8 per cent of the total pulse area of the country. In Odisha, greengram is cultivated in an area of 0.836 million ha with a production of 0.362 million tonnes and productivity of only $434 \mathrm{~kg}$ ha-1 (OAS, 2011). It is grown mainly in rabi and summer seasons after harvest of rice. Ricegreengram cropping system is the most important cropping system in vogue in North Central Plateau Zone of Odisha.

Wheat is one of the most important foods in a balanced diet. In general people starting at the age of 14 should consume approximately 6-7 ounces of grains per day, half of which should come from whole grains (Malakouti, 2000). One ounce of grain, in general, is equal to one slice of bread, one cup of ready-to-eat cereal, or one-half cup of cooked rice, pasta, or cooked cereal. Protein premiums for high quality hard spring wheat have producers concerned with maximizing grain protein levels to capture higher prices (Feldman,1995). The aim of study to determine the concentration of micro and macronutrient in seasonal crops near Lucknow reagion. These nutrients deficiencies in crop are not only hampering the crop productivity but also are deteriorating produce quality.

\section{MATERIALS AND METHODS}

Study area: Lucknow is the capital city of the state of Uttar Pradesh, India. A major metropolitan city of India, Lucknow is the administrative headquarters of the eponymous district and division. It is the 8th most populous city of India and the largest in Uttar Pradesh. Lucknow has always been known as a multicultural city that flourished as a North Indian cultural and artistic hub and seat of Nawab power in the 18th and 19th centuries. It continues to be an important centre of government, education, commerce, aerospace, finance, pharmaceuticals, technology, design, culture, tourism, music and poetry. The Gomti River, Lucknow's chief geographical feature, meanders through the city and divides it into the Trans-Gomti and Cis-Gomti regions. Situated in the middle of the Indus-Gangetic Plain, the city is surrounded by rural towns and villages, the orchard townof Malihabad, Kakori, Mohanlalganj, Gosainganj, Chinhat, and Itaunja. To the east lies Barabanki District, to the west Unnao District, to the south Raebareli District,while to the north lie the Sitapur and Hardoi Districts. Lucknow city I s located in a seismic zone III. Lucknow has a humid subtropical climate with cool, dry winters from November to February and dry, hot summers from April to June. The rainy season is from July to mid-September, when the city gets an average rainfall of 896.2 millimetres (35.28 in) from the south-west monsoon winds. The present study area near Lucknow city as Kakori, Unnao, Barabanki, Malihabad, Bakshi ka Talab and Lakheempur. The soil of this area was more fertile and the former different types of crop produce in the one year for the seasonally. The crop is very important to play its role in farmer economy. Collection of crop samples A, B, C, D, E, and F was directly in the field.

\section{Analysis of plant}

Dry digestion: Dry ashing can be used for sample preparation in the determination of potassium, calcium, magnesium, copper, manganese and iron in plant tissue. It may also be applicable to other elements. A weighed amount of plant material is placed in a crucible and digested (ashed) by heating it in a muffle furnace for several hours. The ash residue is then dissolved in an acid solution, filtered and diluted to a spe- 
Table 1. Nutrient concentrations in different parts of crop.

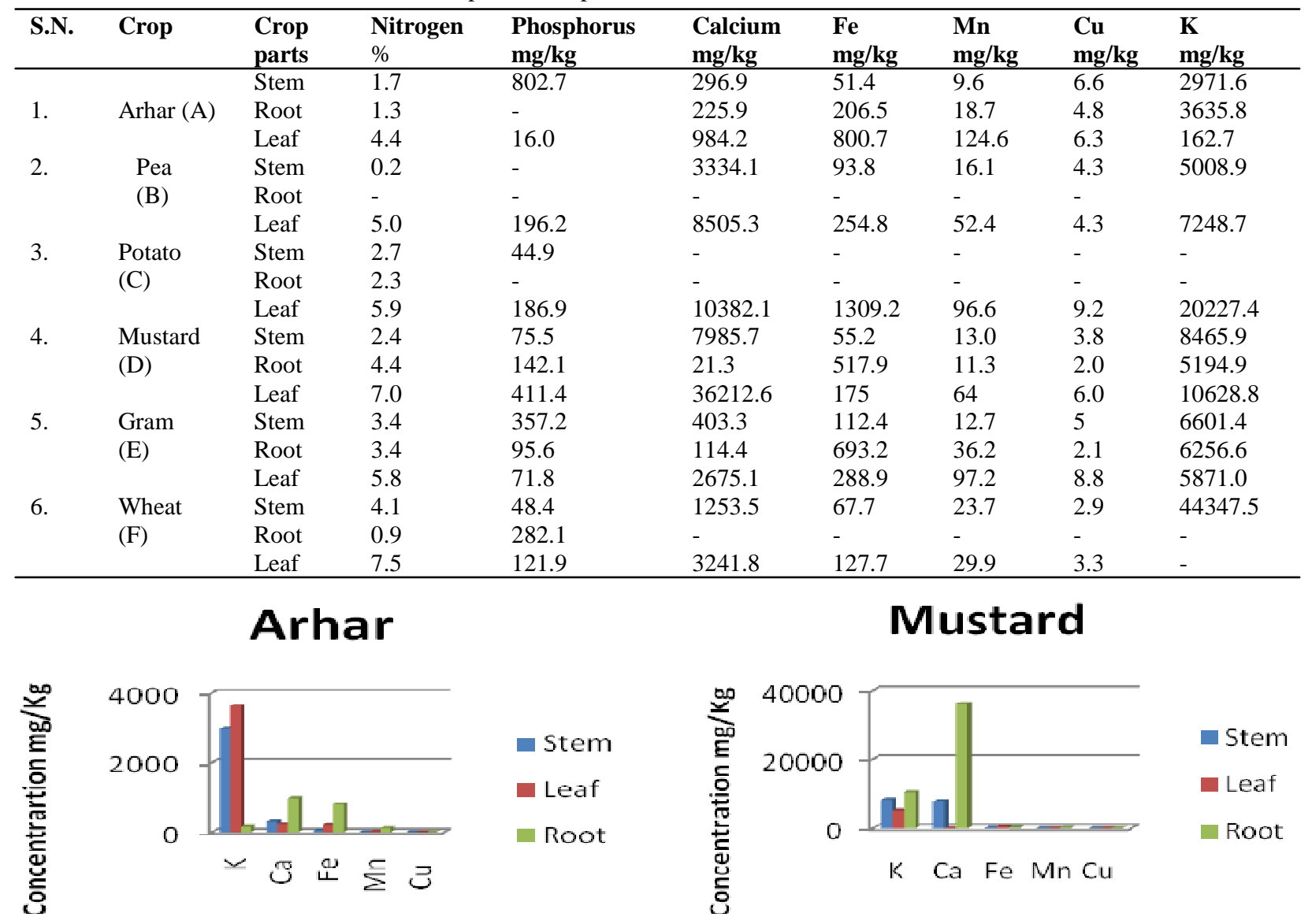

Fig. 1. Concentration of nutrients in Cajanus cajan (Stem, root, leaf of arhar).

\section{Pea}

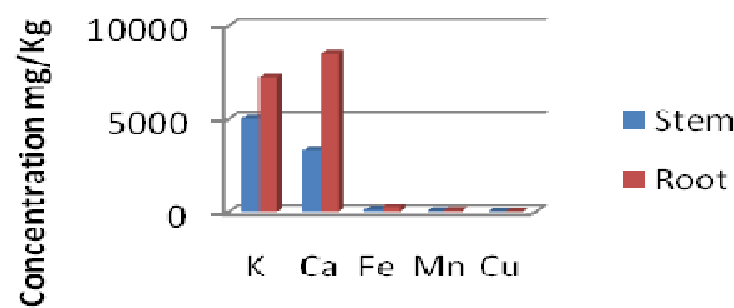

Fig. 2. Concentration of nutrients in the Pisum sativum (Stem, root of pea).

\section{Potato}

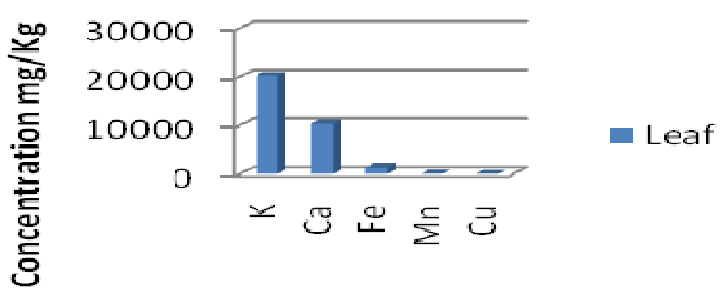

Fig. 3. Concentration of nutrients in the Solanum tuberos (Leaf of potato).
Fig. 4. Concentration of nutrients in the Brassica juncea (Stem, root, leaf of mustard).

\section{Gram}



Fig. 5. Concentration of nutrients in the Cicer arietinum (Stem, root, leaf of gram).

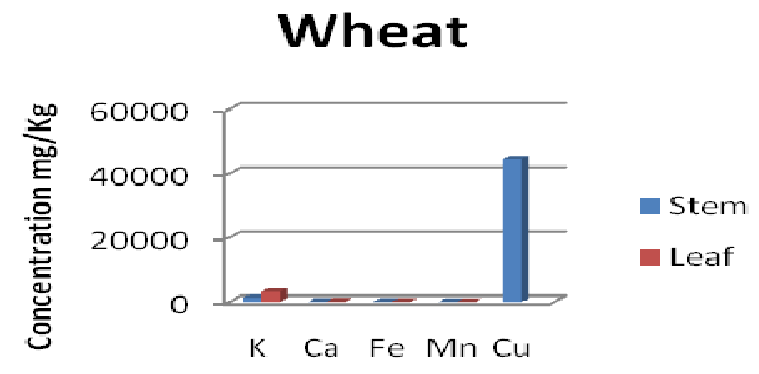

Fig. 6. Concentration of nutrients in the Triticum aestivum (Stem, leaf of wheat). 
cific volume. Dry ashing provides good precision and is an easy, rapid digestion method requiring minimal analyst attention. An additional benefit is that this method is relatively free from reagent contamination. The main disadvantage of this procedure is that it cannot be used for the determination of elements that are volatile below the ashing temperature. The vessels used for ashing range from porcelain to platinum dishes. The sample weight used is between 0.5 and 2.0 $\mathrm{g}$ depending on the expected concentrations of the elements to be determined. The temperature used for ashing ranges from $475{ }^{\circ} \mathrm{C}$ to $600{ }^{\circ} \mathrm{C}$, and the time can be from 4 to 12 hours depending on the sample weight and sample type. The ash residue is usually dissolved in a nitric or hydrochloric acid solution and diluted to volume with deionized water. When determining calcium and magnesium, the final sample dilution should contain $1 \%$ lanthanum to overcome potential anionic interferences. An alcohol- $\mathrm{H}_{2} \mathrm{O}$ mixture is sometimes used to dilute the sample to an appropriate volume. If the concentration of the element of interest is too low, the metal can be complexed and extracted into an organic solvent such as MIBK to increase its concentration (10). Weigh $1 \mathrm{~g}$ of dried, ground plant tissue and place it in a porcelain crucible. Place in a cool muffle furnace and ash at $500{ }^{\circ} \mathrm{C}$ overnight. Cool and dissolve the ash in $5-\mathrm{mL}$ of $20 \% \mathrm{HCl}$, warming the solution, if necessary, to dissolve the residue. Filter the solution through an acidwashed filter paper into a $50-\mathrm{mL}$ volumetric flask. Wash the filter paper. Dilute the solution to volume with deionized water and mix well.

\section{RESULTS AND DISCUSSION}

The present study indicated that the concentration of micronutrients in the selected crop (A, B, C, D, E and F) root, leaf, stem. Analysis is more useful in diagnosing mineral deficiencies and toxicities in tree crops than soil analysis. Copper is an essential element and is always present in food and crop in animal liver, which are the major contributors to dietary exposure to copper (Uauy et al., 1998; DRI 2001). Cu acts as a reluctant in the enzymes superoxide dismutase, cytochrome oxidase, lysyl oxidase, dopamine hydroxylase, and several others oxidises that reduce molecular oxygen. It is transported in the organism by the protein ceruloplasmin (Stern, 2010). The recommended dietary allowance (RDA) for adults is $0.9 \mathrm{mg} /$ day. The present study indicated that the maximum concentration of copper in the crop (Arhar, Pea, Potato, Mustard, Gram, Wheat, 6.6, 4.3, 9.2, 6.0, 8.8, 3.3 mg/kg shown in fig. 1- 6. The macronutrients, i.e., $\mathrm{Ca}, \mathrm{Mg}$, and $\mathrm{K}$ were present in high concentrations in potato leaf, mustard leaf and wheat leaf represented in Table 1. The mineral composition of a leaf is dependent on many factors, such as its stage of development, climatic conditions, availability of mineral elements in the soil, root distribution and activity, irrigation, etc. Leaf samples integrate all these factors, and provide an estimate of which elements are being adequately absorbed by the roots. Pea and mustered had the least number of toxic metals in high concentration and contained most of the macronutrients in optimum to high concentrations, while coriander had micronutrients and toxic metals along with macronutrients in optimum to high concentrations.

Copper is an essential substance to human life, but its critical doses can cause anaemia, acne, adrenal hyperactivity and insufficiency, allergies, hair loss, arthritis, autism, cancer, depression, elevated cholesterol, depression, diabetes, dyslexia, failure to thrive, fatigue, fears, fractures of the bones, headaches, heart attacks, hyperactivity, hypertension, infections, inflammation, kidney and liver dysfunction, panic attacks, strokes, tooth decay and vitamin $\mathrm{C}$ and other vitamin deficiencies (Kabata and Pendias, 1993).

Iron is an important element in human body metabolism which acts as a catalyst and is present in greater amount than any other trace element. Iron (Fe) functions as a component of a number of proteins, including enzymes and haemoglobin. The RDA for both male and female is $8 \mathrm{mg} /$ day and the tolerable upper intake level for adults is $45 \mathrm{mg} /$ day of $\mathrm{Fe}$, which is based on gastrointestinal distress as an adverse effect (DRI, 2001). There is no guideline value sets for $\mathrm{Fe}$ in drinking water by (WHO, 2011).

The metal accumulation was observed to be highest in followed by potato. These samples had higher concentrations of almost all metals evaluated in the study. This can be seen in the relative abundance results tabulated from Table 1. Copper was present in all the samples in low concentrations $(2.0-9.2 \mathrm{mg} / \mathrm{kg})$, while nitrogen, calcium, manganese and potassium were present in moderate to high concentrations in all the vegetables.

\section{Conclusion}

The present studies indicate that the concentration of micro and macro nutrients in selected crop A, B, C, D, $\mathrm{E}$ and $\mathrm{F}$ was present in soil as organic waste; the organic components play an important role in the plant, plant uptake organic compound as a nutrient. Improving crop yield and quality with micro and macro nutrients: Micronutrient deficiency can greatly disturb plant yield and quality, and the health of domestic animals and humans. The current findings indicate that the vegetable plant used for various types of ailments must be checked for heavy metals contamination in order to make it safe for human consumption. In other words, for vegetable crops uses, it should be sown in the areas not contaminated with heavy metals. The current study will also provide useful reference data for the standardization of metal concentration in plant materials.

\section{REFERENCES}

Anonymous (2002). Reducing risks, promoting healthy life. World Health Organization, Geneva, Switzerland. pp 230. 
Bhargava, A., Bouis H and Schrimshaw N. (2001). Dietary intakes and socioeconomic factors are associated with the hemoglobin concentration of Bangladeshi women. $J$. Nutr., 131: 758-764.

Brown, B., (2000). Nitrogen management for hard wheat protein enhancement. University of Idaho Winter Commodity Schools Proceedings- 2000.

Bisht I.S, Bhat, K.V., Lakhanpaul S., Biswas B.K., Ram B., Tanwar S.P.S, (2004). The potential of enhanced germplasm for mungbean (Vigna radiata $(\mathrm{L}$.$) Wilczek) im-$ provement. Plant Genet. Resour., 2(2): 73-80.

DRI (2001). Dietary Reference Intakes for Vitamin A, Vitamin K, Arsenic, Boron, Chromium, Copper, Iodine, Iron, Manganese, Molybdenum, Nickel, Silicon, Vanadium, and Zinc, The National Academies Press, 2001.

Feldman M. (1995). Wheats. In: Smartt J, Simmonds NW, eds. Evolution of crop plants. Harlow, UK: Longman Scientific and Technical, 185-192.

GOI (2013). Agricultural Statistics at a Glance. Government of India, Ministry of Agriculture, Department of Agriculture and Cooperation, Directorate of Economics and Statistics, New Delhi.

Kabata, H. and Pendias, A. (1993). Trace Elements in Soil and Plants, 2nd Edn., Boca Boca Raton FL, USA, 365, Lewis.
Malakouti, M.J. (2000). Balanced nutrition of wheat: An approach towards self-sufficiency and enhancement of national health. "A compilation of papers". Ministry of Agriculture, Karaj, Iran. 544 pp.

OAS (2011). Odisha Agriculture Statistics (Directorate of Agriculture and Food Production, Govt. of Odisha.

Stern B.R. (2010). Essentiality and toxicity in copper health risk assessment: overview, update and regulatory considerations," Journal of Toxicology and Environmental Health A, 73( 2-3): 114-127.

Shylesha, A.N., Azad Thakur, N.S., Pathak, K.A., Rao, K,R., Saikia, K., Surose, S., Kodandaram, N. H and Kalaishekar, A. (2006). Integrated management of insect pest of crops in north eastern hill region. Technical Bulletin No. 19. ICAR RC for NEH Region, Umiam, pp 50.

Shekhawat, K., Rathore, S.S., Premi, O.P., Kandpal, B.K and Chauhan, J.S. (2012). Advances in Agronomic Management of Indian Mustard (Brassica juncea (L.) Czernj. Cosson): An Overview. International Journal of Agronomy. doi:10.1155/2012/408284.

Uauy. R, Olivares. M and Gonzalez M, (1998). Essentiality of copper in humans, The American Journal of Clinical Nutrition, 67(5): 952S-959S

WHO (2011). Guidelines for Drinking-Water Quality, World Health Organisation, 4th edition, 2011. 